\title{
Violência: dimensão do humano?
}

\section{Ademir Pacelli Ferreira*}

Universidade do Estado do Rio de Janeiro - UERJ, Rio de Janeiro, Rio de Janeiro, Brasil

SOUZA, M. de, MARTINS, F., ARAUJO, J. N. G. de, Dimensões da violência: conhecimento, subjetividade e sofrimento psíquico. São Paulo: Casa do Psicólogo, 2011.

A tentativa de ilustrar a violência é sempre um desafio, e exige o enfrentamento de forte resistência. Geralmente os atos ou sistemas violentos são tachados de antihumanos, animais ou desumanos, mas logo pelo título desta coletânea o leitor já sabe que os seus organizadores estão situando a violência nos fundamentos mesmo do humano ao inseri-la na dimensão do conhecimento, da subjetividade e do sofrimento psíquico. Isto é, no seio da vida em comum, onde o mal radical (BIRMAN, 2009) irrompe. E nesta coletânea vamos seguilo em sua presentificação no contrato matrimonial, no trabalho, no interior da família, na escola, no poder e na dominação do outro, nos genocídios, nos extermínios, na submissão e privação de povos e etnias dominadas. Se a modernidade apostou na iluminação do mundo pela ciência e pela razão, no século XX o mal fez a sua marca de forma espantosa, espalhando-se pelos quatro cantos da terra, o que levou Hobsbawm (1995) a afirmar que para construir um mundo mais justo e menos violento, não seria no passado que deveríamos mirar. Teremos que inventar outras possibilidades de convivência local, nacional e entre nações.

Para compor esta coletânea, os organizadores tiveram como proposta dar visibilidade à complexidade que enreda o fenômeno da violência, seguindo a perspectiva das interlocuções disciplinares que perscrutam a suas incidências, do coletivo ao individual. Como disse Primo Levi (1988), no fundo do espírito o outro subjaz como inimigo, logo, podese descarregar nele a agressividade ou usá-lo como objeto de nosso gozo. O que vai concordar também com a perspectiva de Freud (1930), que chama a atenção para a presença desta dimensão de estranhamento e de rejeição do outro que não deve ser negada. Sem os arranjos tênues do Estado e da cultura, ou quando o Estado é tomado pelo mal radical, o ódio ao outro vira sistema ideológico e temos o horror dos genocídios e dos campos de concentração e de extermínio. Portanto, uma temática árdua e que exige coragem para ser explicitada e tratada. Coragem que os organizadores desta 
coletânea tiveram ao implicar importantes autores de diversas linhagens que se debruçaram sobre a tarefa de ilustrá-la com afinco e seriedade.

Neste trabalho, podemos provar a fertilidade destas interlocuções. Como está pontuado por Cardoso de Oliveira no prefácio, o campo das experiências vividas e inseridas no mundo vivido e nas formas de vida, é um campo bastante comum à psicologia e à antropologia. Quando estas duas disciplinas se aproximam e se debruçam sobre esta temática complexa, o resultado desta interlocução é bastante profícuo. Ambas tendem a tomar o mundo social como universo simbolicamente pré-estruturado e o psíquico como dimensão autônoma do substrato biológico. Pode-se dizer que o conjunto dos textos privilegia a dimensão relacional em suas análises da violência, cujas perspectivas abordam o contexto social, a subjetividade e a alteridade.

A partir das várias contribuições que compõem a obra, os organizadores estabeleceram um eixo que as situam em quatro perspectivas. A primeira analisa a tradição do conhecimento moderno que erigiu a concepção do sujeito como verdade e da substância como limite, problematizando o conceito de recalque da diferença que atravessaria a constituição subjetiva e os modos de conhecer que se impuseram hegemonicamente na sociedade ocidental moderna. A segunda incide sobre a dimensão tão idealizada pela modernidade como edificadora do humano, que é o trabalho. Do macro ao micro, a violência no mundo do trabalho é destrinchada de forma abrangente. O que chamei de micro é a presentificação do sofrimento do sujeito trabalhador através da análise do seu drama e de seu percurso na idealizada grande indústria, levantando o véu sobre as perversidades de um sistema. Logo, o sonho de emancipação de um camponês, que acreditava ter encontrado a garantia de um mundo mais firme para criar sua família, é corroído pelo tóxico de seus instrumentos de trabalho e pelo desamparo dos sistemas sanitários. Metáfora dos processos de subjetivação em nosso país, onde está presente o antagonismo campo-cidade, o Jeca Tatu e o urbano cidadão, condições subjetivas que se antagonizam.

$\mathrm{Na}$ terceira perspectiva são analisados os contextos complexos dos aparatos jurídicos e estatais onde estão envolvidas as relações entre poder, gênero e ramificações institucionais. Sistemas de regulagem, de sustentação e de proteção dos elos da cadeia que garantiriam os contratos e as regras da vida em comum, mas que não estão acima do mal humano. Finalmente, os referenciais da psicanálíse e da psicopatologia são acionados para problematizar e ilustrar as ressonâncias da violência em diversos contextos sociais e subjetivos e para pontuar e explicar a desqualificação do eu e do outro para processar os excessos que extravasam em seus atos. 
Podemos entender com Perelson (2011), ao analisar o livro de Birman (2009) sobre a violência, que nesta coletânea há um esforço de fazer-se ouvinte do mal. Recentemente, um jovem ex-aluno de uma escola de um bairro carioca, agora adulto, retornou à escola super armado e sistematicamente descarregou suas armas especiais matando treze crianças e ferindo várias outras. Uma cena-imagem que as televisões rapidamente entraram em ação para encenarem para a população perplexa, o real da cena. Um acontecimento chocante e estarrecedor, ao mesmo tempo invadido pelo excesso de discursos para tentar revelar o velado ou dizer o indizível. Logo após o acontecimento os órgãos de comunicação queriam interpretações, análises, perfis do assassino. Foi bastante repetido que este ato não seria esperado no Brasil, como se fosse possível entendê-lo nos Estados Unidos, mas não aqui. Apesar de ter sido atribuído a um desequilibrado mental, psicopata ou monstro, este ato planejado e executado por um ser humano contra crianças indefesas resta gritante nas mentes. Novamente perguntamos com Levi, é isto o homem?

Portanto, só resta ao leitor aceitar o desafio de enfrentar o que se tem como inapreensível colocado pela violência, entrar na interlocução proposta pelos organizadores e desfrutar desta possibilidade de diálogos interdisciplinares, seguindo os autores em seus esforços de pensar o impensável.

\section{Referências}

BIRMAN, J. Cadernos sobre o mal. Agressividade, violência e crueldade. Rio de Janeiro: Civilização Brasileira, 2009.

FREUD, S. O Mal-Estar na Civilização. Obras Completas, v. XXII. Rio de Janeiro: Imago, 1976.

HOBSBAWM, E. A Era dos Extremos. São Paulo: Cia das Letras, 1995.

LEVI, P. É I sto o Homem? Rio de Janeiro, Rocco, 1988.

PERELSON, S. A escuta do mal radical, v. 14, n. 1. Rio de Janeiro: Ágora, 2011.

\section{Endereço para correspondência}

Ademir Pacelli Ferreira

Universidade do Estado do Rio de Janeiro, Centro de Educação e Humanidades, Departamento de Psicologia Clínica.

Rua São Francisco Xavier, 524 - Maracanã - 20550900 - Rio de Janeiro, RJ - Brasil

Endereço eletrônico: ademirpacelli@uol.com.br

Recebido em: 14/07/2011

Aceito para publicação em: 19/04/2012

Acompanhamento do processo editorial: Alexandra Cleopatre Tsallis 


\section{Notas}

* Professor adjunto, Pró-Cientista, Diretor do Instituto de Psicologia/UERJ entre 2008-2011, onde é professor de psicopatologia, coordenador-supervisor de projetos de extensão junto à Unidade Docente Assistencial de Psiquiatria e do CAPS-UERJ . Supervisor de Estágio Especializado, orientador de projeto de Iniciação Cientifica e professor do Programa de Pós-Graduação em Psicanálise do IP/UERJ. Membro da AUPPF. 